\title{
AXIOLOGICAL STUDIES THE INFLUENCE OF LITERARY WORKS MUSIC FOR HUMAN PHYSICAL CONDITION AND PSYCHOLOGY IN DIGITAL ERA
}

\author{
Saddam Akmal Suryanto', Abdillah Praditya ${ }^{2}$, Febrian Dhani Hartawan ${ }^{3}$, Yoseph Rafael \\ Parlindungan Aruan ${ }^{4}$, Moses Glorino Rumambo Pandin ${ }^{5}$ \\ ${ }^{12,2,45},{ }^{5}$ English Language and Literature Study Program, Faculty of Humanities, Airlangga University Surabaya Campus \\ B, J1. Airlangga No. 4-6, Airlangga, Gubeng Subdistrict, Surabaya City, East Java 60115. (031) 5035676.
}

\author{
${ }^{1}$ saddam.akmal.suryanto-2020@fib.unair.ac.id \\ ªbdillah.praditya-2020@fib.unair.ac.id \\ ${ }^{3}$ febrian.dhani.hartawan-2020@fib.unair.ac.id \\ ${ }^{4}$ yoseph.rafael.parlindungan-2020@fib.unair.ac.id \\ ${ }^{5}$ moses.glorino@fib.unair.ac.id
}

\begin{abstract}
ABSTRAK
Musik adalah seni menyusun nada atau suara dalam urutan, kombinasi, dan hubungan temporal untuk menghasilkan komposisi yang mempunyai satu kesatuan dan kesinambungan. Musik menurut para ahli memiliki pengaruh yang cukup besar bagi kondisi psikologi dan fisik manusia. Penelitian ini bertujuan untuk menganalisis pengaruh musik yang berkaitan dengan kondisi psikologi dan fisik manusia. Penelitian ini menggunakan metode deskriptif melalui pendekatan kualitatif dengan cara survei menggunakan kuesioner dan studi literatur. Dimana dengan metode ini peneliti mendapatkan dua jenis data yaitu data primer dan data sekunder. Dalam hasil penelitian didapatkan sedikitnya 93,9\% atau 31 dari 33 responden mengatakan musik dapat mempengaruhi suasana hati mereka. Sehingga dapat disimpulkan bahwa musik dengan kondisi fisik dan psikologi berkaitan. Faktor yang membuat musik mempunyai pengaruh terhadap psikologi dan kondisi fisik manusia adalah irama, tempo, serta lirik yang berperan penting dalam sebuah lagu sehingga pendengarnya dapat terpengaruh secara psikologi maupun fisik.
\end{abstract}

Kata kunci: Musik, Psikologi, Fisik, Era Digital

\begin{abstract}
Music is an art of composing tones or voices in order, combination, and temporal relations to produce a composition that has one unit and continuity. Music, according to experts, has a considerable impact on the human's physical condition and psychology. This research intended to analyze music's influence related to human psychology and physical condition. This research uses descriptive methods through a qualitative approach by using a questionnaire survey and literature study. With this method, researchers can get two types of data that are primary data and secondary data. In the results of the study, at least $93,9 \%$ or 31 of 33 respondents say music can influence their mood. So that it can be concluded that music with physical condition and psychology are associated. The factors that make music influence human psychology and physical condition are rhythms, tempo, and lyrics that play an important role in a song so the listener can be affected psychologically or physically.
\end{abstract}

Keywords: Music, Psychology, Physical, Digital Era 


\section{PRELIMINARY}

The word music comes from Greek that is Mousikos. According to Andaryani (2019) in Greek mythology, Mousikos is depicted as a god of beauty and ruler of the fields of art and science. Mousikos word generates music words. In the great Indonesian Dictionary (KBBI), music word is defined as the science or art of setting up timbre or voices in order, combination, and temporal relation to creating a composition with one unit and continuity.

Music is a work created by humans that uses sound mediums to enjoy it. Music can be a unity of rhythm, melody, harmony, form, style, and expressions. Music also has high aesthetic value and can make a response from the listener. Many people assume that music can build passion and the spirit of life to empower and define life. By listening to music and enjoying it are fun activities and make us comfortable. Thus positive reactions were born in the physical and psychological condition of humans medically. (Lestari, Claudia, Darminah, and Ainun 2019)

As time progressed, music was created in various variations. These things produce various popular music genres that are known. Not only about love and broken heart or friendship, but music also grows with many mental health themes, which contains an invitation to keep the spirit and respect yourself in this modern era (Najla, 2020).

Music is well known in our life, people around the world explain that humans have enjoyed music since the stone age. Until now, music has become a "friend" when people carry out life activities such as studying, sleeping, cooking, when they are alone, including when doing homework. (Izzah, Rahmawati, Humairoh, 2019).

Shaleha's research (2019) shows that basic emotions delivered from the creator through music tend to be perceived by listeners according to their own cultural background. From that research, it can be concluded that music has a different emotional effect for each person according to their cultural background. This thing is because their own emotional experience caused by music can have an impact on behavior, emotion, and positive motivation. Positive emotional experiences obtained from listening to music can make someone able to assess life as an opportunity to grow (Juliana, 2021).

Rahayu (2020) stated that Music therapy has been widely used to relieve emotional strain, specifically individual worries and suffering throughout the pregnancy period, and provides a method for the birth process. Then, from this research, we can conclude that music has an impact on an individual's emotions as well as their physical health.

Pratama and Puspitosari (2019) also reported that using various types of music therapy as treatment resulted in a considerable reduction in symptoms of mental stress in the elderly. This demonstrates the importance of music in human medicine. In the sense that music has a profound effect on someone's mental health.

Music is also considered a useful method to spread Islamic teachings. M. Azis Zikri, Secretary-General of East Bandung stated that music is permitted and required if it becomes the way to know the religion of Islam and to learn about it. (Wulandari, Aliyudin, dan Dewi, 2019)

This paper aims to prove that music has a connection and influence on human psychology and physical condition. Lyrics and melody arrangements have psychological and physical influences on humans. Yet, as far as the research done by the author, there has been no research on the 
influence of literary works music toward someone's physical condition and psychology in the digital era. What kind of influence is felt after hearing music?. Does a person's mood change have anything to do with music with a particular genre? What is the difference between music before the digital era and music in the digital era?.

The benefit for the author is as a place to pour the results of the thoughts that have been used as research material. The benefit for the readers is the reader can find out the cause and influence of music on their psychology and physical condition that they feel after listening to music. So that the reader can express themselves more through music. The benefit for society is to add insight for the general public about psychology or music knowledge.

\section{RESEARCH METHODS}

In this study, the researcher uses descriptive methods with a qualitative approach, which researcher aims to get the most accurate facts in fields and various characteristics on research objects. The population in this research are 33 respondents with the age range 18-21 years old who have or often listened to music. Our research objects are the younger generation with the age range 18-21 years old. The reason researchers choose 18-21 years old respondents is because in this phase adolescents already have prominent self-identity, have logical thought, and have a desire to achieve emotional dependence. Researchers assume that with the emotional stability possessed by teenagers around 18-21 years old, they can feel the influence and relations of music with their physical condition or their psychology. The research focus that the researcher does is to find the influence of music on the physical condition and psychology of respondents on a daily basis and when they are doing their activities. The analytical techniques used are descriptive analysis techniques where the results of the answer are presented using descriptive tables.

In collecting the data, this study used a questionnaire survey method by including personal questions directly to respondents using a google form. Researchers used three types of questions included in the research questionnaire.

1. Multiple choice question, this type of question will provide answer choices that can be chosen by more than one respondent.

2. Dichotomous question is a question that can have two possible answers. This type of question requires the respondent to choose one answer.

3. Stapel scale questions is a close-ended question using the rating method that allows respondents to rate according to their perspective.

In this study, the respondents are university students who are still pursuing undergraduate education. Considering that they are teenagers who like to listen to music the researchers concluded that they have many similarities in listening to music genres. The data collected is divided into two, primary data and secondary data.

1. Primary data is data obtained from respondents' answers to questionnaires via google forms that have been distributed on various social media platforms.

2. Secondary data is data obtained from literature studies in the form of books, articles, and journals to find relevant theories to research on the influence of music in psychology and the physical condition of humans in the digital era.

Here is a flow chart of the research process that we did:

Table 1. Research Flow Using Qualitative Research Methods and Analytical Techniques

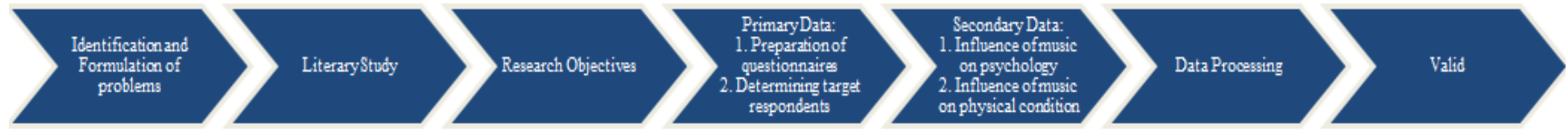




\section{RESULTS}

Table 2. Survey Results

\begin{tabular}{|c|c|c|}
\hline Questions & Option & Turnout (Percentage) \\
\hline $\begin{array}{l}\text { Do you think music can affect } \\
\text { your mood? }\end{array}$ & $\begin{array}{l}\text { 1. Yes } \\
\text { 2. No } \\
\text { 3. Maybe }\end{array}$ & $\begin{array}{ll}\text { 1. } & 31(93,9 \%) \\
\text { 2. } & 1(3 \%) \\
\text { 3. } & 1(3 \%)\end{array}$ \\
\hline $\begin{array}{l}\text { Do you ever feel that music } \\
\text { increases the activity capacity } \\
\text { that you are doing? }\end{array}$ & $\begin{array}{ll}\text { 1. } & \text { Ever } \\
\text { 2. Never } \\
\text { 3. } & \text { Not Sure }\end{array}$ & $\begin{array}{ll}\text { 1. } & 30(90,9 \%) \\
\text { 2. } & 0(0 \%) \\
\text { 3. } & 3(9,1 \%)\end{array}$ \\
\hline $\begin{array}{l}\text { Have you ever felt music restore } \\
\text { your feelings when you were } \\
\text { feeling depressed? }\end{array}$ & $\begin{array}{ll}\text { 1. } & \text { Ever } \\
\text { 2. Never } \\
\text { 3. } & \text { Maybe }\end{array}$ & $\begin{array}{ll}\text { 1. } & 30(90,9 \%) \\
\text { 2. } & 1(3 \%) \\
\text { 3. } & 2(6,1 \%)\end{array}$ \\
\hline $\begin{array}{l}\text { What's your favorite app to listen } \\
\text { to music? (You can choose more } \\
\text { than } 1 \text { ) }\end{array}$ & $\begin{array}{ll}\text { 1. } & \text { Spotify } \\
\text { 2. } & \text { Joox } \\
\text { 3. } & \text { YouTube } \\
\text { 4. } & \text { SoundCloud } \\
\text { 5. } & \text { Apple Music } \\
\text { 6. } & \text { Deezer } \\
\text { 7. } & \text { Radio }\end{array}$ & $\begin{array}{ll}1 . & 25(75,8 \%) \\
2 . & 5(15,3 \%) \\
3 . & 31(93,9 \%) \\
4 . & 6(18,2 \%) \\
5 . & 6(18,2 \%) \\
6 . & 1(3 \%) \\
7 . & 1(3 \%)\end{array}$ \\
\hline $\begin{array}{l}\text { On a scale of } 1 \text { (very difficult) to } \\
5 \text { (very easy), how easy can you } \\
\text { access music services in today's } \\
\text { digital era? }\end{array}$ & $\begin{array}{ll}\text { 1. } & 1 \\
\text { 2. } & 2 \\
\text { 3. } & 3 \\
\text { 4. } & 4 \\
\text { 5. } & 5\end{array}$ & $\begin{array}{ll}1 . & 0(0 \%) \\
2 . & 0(0 \%) \\
3 . & 0(0 \%) \\
4 . & 3(9,1 \%) \\
5 . & 30(90,9 \%)\end{array}$ \\
\hline
\end{tabular}

Table 3. Interview Results

\begin{tabular}{|c|c|c|c|c|c|c|c|}
\hline No & Questions & Anin & Dicky & Michael & Verrol & Rinaldi & Hanif \\
\hline 1. & $\begin{array}{l}\text { What effect do } \\
\text { you feel when } \\
\text { you hear music } \\
\text { on your mood, } \\
\text { mental, and } \\
\text { mind? }\end{array}$ & $\begin{array}{l}\text { Get lost in the } \\
\text { expression, it } \\
\text { brings back } \\
\text { memories } \\
\text { related to the } \\
\text { music. }\end{array}$ & $\begin{array}{l}\text { Reminding } \\
\text { many } \\
\text { experiences, } \\
\text { happy and sad } \\
\text { memories } \\
\text { according to } \\
\text { the genre of } \\
\text { music I was } \\
\text { listening to. }\end{array}$ & $\begin{array}{l}\text { It makes me } \\
\text { remember the } \\
\text { past and } \\
\text { sometimes } \\
\text { makes me } \\
\text { nostalgic. }\end{array}$ & $\begin{array}{l}\text { It makes my } \\
\text { mood feel } \\
\text { comfortable, } \\
\text { calm, and } \\
\text { peaceful. } \\
\text { Sometimes I } \\
\text { feel excited } \\
\text { too. }\end{array}$ & $\begin{array}{l}\text { Music makes } \\
\text { me feel more } \\
\text { excited to go } \\
\text { about my } \\
\text { daily } \\
\text { activities and } \\
\text { makes me } \\
\text { have a lot of } \\
\text { ideas. }\end{array}$ & $\begin{array}{c}\text { My daily } \\
\text { activities } \\
\text { become } \\
\text { more } \\
\text { colorful } \\
\text { and I also } \\
\text { become } \\
\text { excited in } \\
\text { everyday } \\
\text { life. }\end{array}$ \\
\hline
\end{tabular}




\begin{tabular}{|c|c|c|c|c|c|c|c|}
\hline 2. & $\begin{array}{l}\text { Do you have a } \\
\text { preference for } \\
\text { certain genres of } \\
\text { music and how } \\
\text { does it affect } \\
\text { your physical } \\
\text { condition? }\end{array}$ & $\begin{array}{l}\text { Hip Hop, } \\
\text { EDM, rock, } \\
\text { (music with a } \\
\text { strong beat). } \\
\text { Makes me so } \\
\text { excited and } \\
\text { forget the sad } \\
\text { feelings that } \\
\text { exist. }\end{array}$ & $\begin{array}{l}\text { Pop, because } \\
\text { the music } \\
\text { sometimes } \\
\text { makes me sad } \\
\text { because it } \\
\text { relates to my } \\
\text { life. }\end{array}$ & $\begin{array}{l}\text { I think pop } \\
\text { because it } \\
\text { makes me } \\
\text { have a high } \\
\text { sense of spirit } \\
\text { to do things } \\
\text { that I enjoy } \\
\text { like exercising } \\
\text { or other } \\
\text { activities. }\end{array}$ & $\begin{array}{l}\text { I love rock } \\
\text { music } \\
\text { because it } \\
\text { makes me } \\
\text { more excited } \\
\text { about sports } \\
\text { that can } \\
\text { improve my } \\
\text { physical } \\
\text { abilities. }\end{array}$ & $\begin{array}{l}\text { Rock, jazz, } \\
\text { and metal. } \\
\text { The music } \\
\text { made me } \\
\text { more excited } \\
\text { to do my } \\
\text { activities. }\end{array}$ & $\begin{array}{l}\text { The music } \\
\text { I love is } \\
\text { EDM. } \\
\text { Because } \\
\text { with the } \\
\text { accompani } \\
\text { ment of } \\
\text { music that } \\
\text { is what } \\
\text { makes me } \\
\text { enjoy it } \\
\text { when } \\
\text { listening to } \\
\text { it. }\end{array}$ \\
\hline 3. & $\begin{array}{l}\text { Does music ever } \\
\text { or often make } \\
\text { you excited to do } \\
\text { activities or } \\
\text { hinder your } \\
\text { activities? }\end{array}$ & $\begin{array}{l}\text { Yes, it makes } \\
\text { me excited, but } \\
\text { sometimes } \\
\text { inhibiting, } \\
\text { because when I } \\
\text { do something, } \\
\text { during a chorus } \\
\text { or a certain } \\
\text { favorite part, I } \\
\text { tend to stop } \\
\text { doing that and } \\
\text { instead sing, } \\
\text { and lose focus. }\end{array}$ & $\begin{array}{l}\text { Sometimes it } \\
\text { makes me } \\
\text { excited, but } \\
\text { sometimes it } \\
\text { makes me sad } \\
\text { so I tend not to } \\
\text { be passionate } \\
\text { about carrying } \\
\text { out my } \\
\text { activities. }\end{array}$ & $\begin{array}{l}\text { Yes, I've felt } \\
\text { that music } \\
\text { makes me } \\
\text { excited about } \\
\text { my activities, } \\
\text { but sometimes } \\
\text { it also gets me } \\
\text { carried away. }\end{array}$ & $\begin{array}{l}\text { Sometimes } \\
\text { music makes } \\
\text { me feel sad } \\
\text { also because } \\
\text { the meaning } \\
\text { of the song I } \\
\text { listen to has } \\
\text { a sad } \\
\text { element, } \\
\text { especially } \\
\text { about } \\
\text { romance. }\end{array}$ & $\begin{array}{l}\text { Quite often, I } \\
\text { channel my } \\
\text { emotions by } \\
\text { listening to } \\
\text { the music of } \\
\text { a certain } \\
\text { genre to } \\
\text { build } \\
\text { passion. }\end{array}$ & $\begin{array}{l}\text { I could say } \\
\text { it often, } \\
\text { because I } \\
\text { have a } \\
\text { habit of } \\
\text { exercise } \\
\text { and I also } \\
\text { listen to } \\
\text { music that } \\
\text { makes me } \\
\text { become } \\
\text { encouraged } \\
\text { and } \\
\text { passionate } \\
\text { in carrying } \\
\text { it out. }\end{array}$ \\
\hline 4. & $\begin{array}{l}\text { How does the } \\
\text { digital age affect } \\
\text { the intensity of } \\
\text { your music } \\
\text { listening? }\end{array}$ & $\begin{array}{l}\text { Not very } \\
\text { influential. } \\
\text { because } \\
\text { listening to } \\
\text { music suits my } \\
\text { mood. }\end{array}$ & $\begin{array}{l}\text { Quite } \\
\text { influential, } \\
\text { because the } \\
\text { digital era can } \\
\text { make us able } \\
\text { to listen to } \\
\text { music anytime } \\
\text { and anywhere } \\
\text { that makes the } \\
\text { intensity of } \\
\text { listening to } \\
\text { music even } \\
\text { greater. }\end{array}$ & $\begin{array}{c}\text { Very } \\
\text { influential, } \\
\text { with the ease } \\
\text { in this digital } \\
\text { era, the } \\
\text { intensity to } \\
\text { listen to music } \\
\text { becomes more } \\
\text { frequent. }\end{array}$ & $\begin{array}{l}\text { In this digital } \\
\text { age, it has } \\
\text { become } \\
\text { easier for me } \\
\text { to access a } \\
\text { wide variety } \\
\text { of platforms } \\
\text { to listen to } \\
\text { the latest } \\
\text { music. I } \\
\text { listen to } \\
\text { music every } \\
\text { day. }\end{array}$ & $\begin{array}{l}\text { With the ease } \\
\text { that I get } \\
\text { from this } \\
\text { digital era, of } \\
\text { course, I } \\
\text { become more } \\
\text { often } \\
\text { listening to } \\
\text { music. }\end{array}$ & $\begin{array}{l}\text { There's a } \\
\text { lot of new } \\
\text { music in } \\
\text { this day } \\
\text { and age. } \\
\text { The ease of } \\
\text { accessing it } \\
\text { is the most } \\
\text { important } \\
\text { thing for } \\
\text { me. In this } \\
\text { digital era, } \\
\text { I am very } \\
\text { facilitated } \\
\text { by the } \\
\text { presence of } \\
\text { various } \\
\text { music } \\
\text { platforms. }\end{array}$ \\
\hline
\end{tabular}




\begin{tabular}{|c|c|c|c|c|c|c|c|}
\hline 5. & $\begin{array}{l}\text { Besides music, is } \\
\text { there any other } \\
\text { media that } \\
\text { makes your } \\
\text { mood or mind } \\
\text { calm? }\end{array}$ & $\begin{array}{c}\text { Reading } \\
\text { comics or } \\
\text { watching } \\
\text { movies help to } \\
\text { relieve negative } \\
\text { feelings in me. }\end{array}$ & $\begin{array}{l}\text { Watching } \\
\text { movies and } \\
\text { exercising can } \\
\text { make me more } \\
\text { excited. }\end{array}$ & $\begin{array}{l}\text { Playing on } \\
\text { social media } \\
\text { can help me } \\
\text { freshen my } \\
\text { thoughts. }\end{array}$ & $\begin{array}{l}\text { I could say } \\
\text { reading } \\
\text { novels is } \\
\text { another way } \\
\text { for me to } \\
\text { achieve } \\
\text { peace of } \\
\text { mind. }\end{array}$ & $\begin{array}{c}\text { Playing } \\
\text { games, in my } \\
\text { opinion, is a } \\
\text { good way for } \\
\text { me to express } \\
\text { my emotions } \\
\text { and stress. }\end{array}$ & $\begin{array}{l}\text { Reading } \\
\text { comics and } \\
\text { novels help } \\
\text { me to think } \\
\text { more } \\
\text { clearly. }\end{array}$ \\
\hline
\end{tabular}

Our survey ended with a total of 33 respondents students with age range 18-21 years old that collected through Google Form. From the results listed in table 2 as $93,9 \%$ with a total of 31 people, states agree that music can have an influence on the listener's mood. Meanwhile, as many as $3 \%$ of respondents who amounted to 1 person said music did not affect the mood of the listener, then another $3 \%$ of 1 person answered maybe.

The researchers also asked the respondents if they had ever felt that music boosted their capacity for whatever activity they were doing in table 2 . Music has had a positive impact on boosting the capability of the activities that 90.9 percent of respondents (a total of 30 persons) have participated in. The remaining $9.1 \%$ of respondents (a total of three participants) said they were unsure about the influence of music on boosting the capacity of the activities they participated in. Those who did not choose the last choice, as many as $0 \%$ of respondents, never felt the effect of music on improving activity capacity.

In table 2 number 3 researchers give questions that are associated with music that can restore feelings when someone feels depressed. As many as 30 people $(90,9 \%)$ answered that music restores feelings when they feel depressed. Then, there is 1 person $(3 \%)$ that considers music does not restore the feelings when they are depressed. Last, as many as 2 people $(6,1 \%)$ choose option maybe. It can be concluded that music does not always restore feelings when depressed depending on the kind of music they listen to.

Talking about the favorite platform that is often used by 33 respondents, there are 7 choices that the researcher provides. Here is the platform and percentage that use it, $25(75,8 \%)$ people selected Spotify, 5 (15,3\%) selected Joox, 31 (93,9\%) people selected YouTube, 6 (18,2\%) selected SoundCloud, 6 (18,2\%) selected Apple Music, 1 (3\%) selected Deezer, and 1 (3\%) selected. Following the survey conducted, the most used platform is YouTube.

Researchers also asked on a scale of 1-5 how easy it is for respondents to access music service platforms in the current digital era. On a scale of 5, as many as $90.9 \%$ or 30 people chose it. While those who answered on a scale of 4 were $9.1 \%$ with a total of 3 people. As for the 1-3 scale options, no one chooses or $0 \%$.

\section{DISCUSSION}

$93,9 \%$ of the respondents that agreed that music affects their disposition can be used as a basis to conclude that the hypothesis-that music has a significant influence on a person's psychological condition-can be considered true. The results in this study are similar to the findings of dr. Fadhli Rizal Makarim (2019); who stated that music can make those who hear it feel happier and motivates them to do more activities.

$90,9 \%$ of the respondents in this study agreed that music also procured physical benefits on top of the psychological benefits. Fatahilah et al. (2019) conducted a study on the correlation between music listening and performance in routine jogging. In their study, they found that the participants that did not listen 
to music jogged a lesser distance and in a shorter duration than those who had listened to music every time they jog. Further inquiries asserted the causes: regulating breath becomes easier as the tempo can be adjusted to the music, rather than giving it a rough estimate; and heartbeats as well as footsteps subconsciously follow the rhythm of the music participants were listening to.

30 of 33 respondents experienced tranquility during stressful situations due to music relieving them of pressure. Music has been believed to help with anxiety which is defined by the American Psychological Association as a change in emotion caused by loss of control of a certain situation accompanied by the change of blood pressure and a worrisome feeling (Supardi, Artawan, \& Pakan; 2020). As demonstrated by the previous responses and theories, the psychological and physical changes brought on by music also benefits individuals experiencing anxiety. Both the blood pressure change, as well as the worrisome sensation, can be negated by music that the particular individual prefers.

The intensity of music consumption increasing in the current years, including in teenagers, has been due to the increased ease of access to musical content. The conception of various platforms and services that can be accessed anywhere at any point in time has jump-started a rise of interest in music compared to before said services existed. By erasing the necessity of physical objects such as cassettes, optical drives, and vinyl records-replaced with the necessity of a simple smartphone or computer; it has been considerably easier for people to appreciate music, whether just starting out or continuing their hobby.

\section{CONCLUSION}

Based on the results of the research and discussion above, the researcher can conclude that in this digital era, music can affect human physical and psychological conditions. Music can help restore physical and psychological conditions and vice versa, music can also reduce physical and psychological conditions for listeners. Music also helps listeners to stay calm in stressful conditions. However, sometimes listeners get carried away by the sad atmosphere brought by the music so that it affects the mood of music listeners. From this impact, it can lead to a decrease in enthusiasm, self-confidence, and loss of focus which has an impact on a person's physical condition. To overcome this problem, it can be done by changing the type of music that will be listened to so that the sense of enthusiasm, confidence, and focus can increase so that they can carry out activities in excellent physical condition. Choosing the right music genre with a fast-paced rhythm and having uplifting lyrics such as EDM, Hip Hop, Rock, and Dangdut will help music listeners to return their passion. Changes in a person's mood are also influenced by certain genres of music. If the listener listens to a song with a slow rhythm and sad song lyrics, the listener's mood will also dissolve in sadness. On the other hand, if the listener listens to a song with a fast-paced rhythm and uplifting lyrics, the listener's mood will also be excited. Rhythm, tempo, and lyrics in the song have a significant influence on the listener's mood. Therefore, music genres that have different rhythms, tempos, and lyrics influence a person's mood, so it can be concluded that music genres also determine the mood of the listener. Furthermore, the process of changing music in this digital era compared to before can be seen if in the current era we are now easy to access all kinds of music platforms and even music concerts that are usually held in open fields can now be held in closed places and can be accessed publicly online. In addition, recently many new musicians have emerged, especially from the young. These young musicians can attract the attention of millennials with their enjoyable works. The existence of a talent search event is very helpful in bringing out new talents, especially singers. This is what distinguishes the development of music in this digital era from before. It is hoped that this digital era will bring an innovation that can be developed by all Indonesian people.

\section{BIBLIOGRAPHY}

Andaryani, E. (2019). Pengaruh Musik Sebagai Moodboster Mahasiswa. Musikolastika: Jurnal Pertunjukan Dan Pendidikan Musik, 1(2), 109-115. https://doi.org/10.24036/musikolastika.v1i2.31

Najla, A. N. (2020). Dampak Mendengarkan Musik Terhadap Kondisi PSIKOLOGIS remaja. https://doi.org/10.31234/osf.io/fwuin 
Shaleha, R. R. (2019). Do re mi: Psikologi, Musik, Dan Budaya. Buletin Psikologi, 27(1), 43. https://doi.org/10.22146/buletinpsikologi.37152

Izzah L,Rahmawati,Humairoh H. (2019). Pengaruh Mendengarkan Musik Terhadap Mood Belajar Pada Mahasiswa Manajemen Dakwah UIN Suaka Riau.

https://media.neliti.com/media/publications/327950-pengaruh-mendengarkan-musik-terhadap-moo-f0fff377. pdf.

Juliana, Y. (2020, September 1). Hubungan preferensi Musik Dengan psychological well-being pada remaja akhir. Unair Repository. Retrieved on December 16, 2021, from https://repository.unair.ac.id/98216/

Rahayu, D. E. (2020). Efektifitas Terapi Musik Terhadap Pencegahan Postpartum Blues Pada Ibu Primipara. Journal for Quality in Women's Health, 3(2), 254. https://doi.org/10.30994/iqwh.v3i2.95

T. Lestari,R. Claudia ,Darminah,Ainun (25 November 2019), Pengaruh Musik Terhadap Gairah, Kenikmatan Musik, Dan Kinerja Kognitif Pada Mahasiswa UIN Sunan Kalijaga Yogyakarta.

Pratama, R. N., \& Puspitosari, W. A. (2019). Terapi Musik Dalam menurunkan Tingkat Depresi Pada Lansia. Jurnal Keperawatan Respati Yogyakarta, 6(2), 606. https://doi.org/10.35842/ikry.v6i2.302

Wulandari, T. S., Aliyudin, M., \& Dewi, R. (2019). Musik Sebagai media Dakwah. Tabligh: Jurnal Komunikasi Dan Penyiaran Islam, 4(4), 448-466. https://doi.org/10.15575/tabligh.v4i4.1089

Makarim, F. R. (2019, July 9). Gemar Musik, Ini Manfaatnya untuk kesehatan mental. halodoc. Retrieved December 28, 2021, from https://www.halodoc.com/artikel/gemar-musik-ini-manfaatnya-untuk-kesehatan-mental

Supardi, F. J., Artawan, I. M., \& Pakan, P. D. (2020). Pengaruh Pemberian Terapi Musik Klasik Terhadap Tingkat Kecemasan Pasien Pre-Operasi di RSUD Prof. Dr. WZ Johannes Kupang. Cendana Medical Journal (CMJ), 8(2), 118-123.

Rahman, R. (2021, August). Efektivitas Musik Jazz terhadap Kecerdasan Emosional (EQ) pada Siswa KELAS VII SMP Negeri 1 Sedayu. In Prosiding Seminar Nasional Bimbingan dan Konseling Universitas Ahmad Dahlan (Vol. 1).

Prey, R., Esteve Del Valle, M., \& Zwerwer, L. (2020). Platform pop: disentangling Spotify's intermediary role in the music industry. Information, Communication \& Society, 1-19.

https://doi.org/10.1080/1369118x.2020.1761859

\section{ATTACHMENTS}

\begin{tabular}{|l|l|l|l|}
\hline No & \multicolumn{1}{|c|}{ Questions } & \multicolumn{1}{|c|}{ Option } & \multicolumn{1}{|c|}{$\begin{array}{c}\text { Percentage (Number of } \\
\text { respondents) }\end{array}$} \\
\hline 1. & $\begin{array}{l}\text { Does music play an important role } \\
\text { in your mental health? }\end{array}$ & $\begin{array}{l}\text { 1. Yes } \\
\text { 2. No } \\
\text { 3. Maybe }\end{array}$ & $\begin{array}{l}\text { 1. } 81,8 \%(27) \\
\text { 3. } 0 \%(0) \\
18,2 \%(6)\end{array}$ \\
\hline 2. & $\begin{array}{l}\text { In your opinion, is it possible that } \\
\text { music can make listeners depressed } \\
\text { or stressed? }\end{array}$ & $\begin{array}{l}\text { 1. Yes } \\
\text { 2. No }\end{array}$ & $\begin{array}{l}\text { 1. } 60,6 \%(20) \\
29,4 \%(13)\end{array}$ \\
\hline
\end{tabular}

Total respondents: 33 
Focus: Teenagers aged 18-21 years old

Methods: Questionnaires survey 